\title{
The relationship between social capital and objective welfare of cocoa farmer households in Tolada Village, North Luwu Regency, South Sulawesi, Indonesia
}

\author{
Heliawaty , Pipi Diansari, Darmawan Salman, Rahmadanih, and A. Ramdana Widyayani \\ Department of Agricultural Social Economics, Faculty of Agriculture, Hasanuddin University, \\ Makassar, Indonesia
}

\begin{abstract}
Social capital is an important aspect of developing more advanced agriculture. Community social capital, such as trust, mutual cooperation, networks and attitudes, play a major role in community behaviour, and if managed properly, it will be able to empower the community. Various elements of social capital found in rural areas are alleged to be able to contribute to the objective welfare of rural communities, especially farmers. This research uses $\mathrm{s}$ descriptive quantitative research method, namely the method used to measure and describe the data regarding the elements of social capital owned by cocoa farmers (trust and network) and their relationship with objective economic welfare. The purpose of this study was to determine the relationship between social capital and the objective welfare of cocoa farmer households. The results showed that the correlation value of social capital and objective welfare was in the medium category, where the social capital of the farmer's life took place in an intimate, mutual trust and could take advantage of the existing network to collaborate to solve agricultural problems.
\end{abstract}

\section{Introduction}

Economic development sector, social capital has a very high influence on the development and progress of various economic sectors, one of which is in the agricultural sector $[1,2]$. Busthanul, et al. [3] stated that social capital is a very important development capital for the life of rural communities. Diniyati (in Busthanul et al, 2016) explains that social capital is an important concept in sustainable agricultural development programs [3]. Social capital has a major influence on the development and progress of various economic sectors [4]. The strength of social relationships is reflected in good behavior, a sense of friendship, mutual sympathy, and fostering close cooperative relationships between individuals in the family who form a social group in social life [5].

*Corresponding author: heliawaty_adwiawan@yahoo.com 
Social capital is an important aspect for developing a more advanced agriculture [6]. Community social capital, such as trust, mutual cooperation, networks and attitudes, play a major role in community behavior and, if managed properly, can empower the community $[7,8]$. Social capital is a shared norm and value generated by trust, where trust is the basis for an attitude of order, honesty, and cooperative behavior that emerges from within a community. The social capital dimension describes everything that brings society together to achieve goals on the basis of togetherness [9].

The role of social capital in small-scale agriculture has been widely recognized and the growth effects of social capital can be manifested in networking and trust in productive resources and knowledge sharing among farmers [10,11]. Community collective action can be facilitated by social capital and has a strong influence on the process of increasing the social welfare of the community $[12,13]$. Social capital will have an impact on high community participation, so that the government will have stronger accountability [14]. Good application of social capital is able to empower communities and is very influential in the success of natural resource management $[15,16]$.

The development of agriculture in the plantation sub-sector has an important meaning, especially in developing countries which always strive to utilize natural resources in a sustainable manner. Indonesia is a country whose territory is a tropical area so that it experiences heavy rain and sunshine almost all the time, which are important elements for the growth and development of plantation crops. South Sulawesi is an area where the majority of the population works as farmers who work a lot on cocoa commodities. In 2018, the number of cocoa farmers in South Sulawesi was 267,574 people [17] and in 2019 the number of cocoa farmers in South Sulawesi decreased to 252,429 people [18]. The decline in the number of farmers by 15,145 people was due to farmers and farm laborers experiencing a decline in economic welfare, so that farmers and farm laborers switched their livelihoods to other sectors. This is also triggered by the absence of welfare guarantees for farmers that are supported by policies so that they do not make farmers free from poverty shackles [19].

The family is said to be prosperous if it is able to materially fulfill all the family's needs [20]. It is hoped that farmers' welfare can be achieved by utilizing their cocoa plantation land. The area of cocoa plantation in South Sulawesi is 240,635 Ha [17]. North Luwu Regency is one of the regions of South Sulawesi which is the center of the cocoa development area and places cocoa as a leading commodity which has a production area of 37,713 hectares of cocoa land with a production of 26,567 tons and a total of 26,963 cocoa farmers [17]. This gives North Luwu district the potential to become a large cocoa production center if it is well developed, as has been done by the people of Tolada Village, Malangke District, North Luwu Regency. Tolada village is a village that has developed a lot of cocoa plants, the people of which depend a lot on farming cocoa.

Tolada village has been able to meet most of the growing factors for cocoa, making it a very potential area to develop cocoa plants, which are expected to contribute to the welfare of farmer households if they are able to maximize yields by utilizing all available resources. Social capital is a resource that is owned by an individual community who is able and willing to interact together with other people to solve problems together by using the resources they have, both privately and in general [21].

Various elements of social capital in rural areas are alleged to be able to contribute to rural communities, especially farmers. The elements of farmer social capital are trust and network. Trust is one of the most important synthetic forces in society, trust is also a basis for individual action and a basis for good cooperation [22]. The network is a dynamic infrastructure in the form of networks of cooperation between people. These networks facilitate communication and interaction, enable trust to grow and strengthen collaboration [23]. The two elements of social capital, trust and network, can be linked to the objective 
welfare of the farmer household. Based on this description, it is interesting to conduct research to examine "The Relationship between Cocoa Farmers 'Social Capital and the Level of Objective Welfare of Cocoa Farmers' Households in Tolada Village, Malangke District.

\section{Research methodology}

The research method used in this research is quantitative descriptive research, namely the method used to measure and describe the data regarding the elements of social capital owned by cocoa farmers (trust and network) and their relationship with objective economic welfare. Descriptive research is conducted quantitatively so that statistical analysis can be carried out. In this case, it needs to be understood that the quantitative method is a method that prioritizes information through numbers so that the symptoms in the study can be measured by scales [24].

\section{Result and discussion}

\subsection{Test research instruments}

To find out whether the instrument compiled is a good instrument for research, a research instrument test is carried out, namely the validity test and the reliability test. The research instrument can be said to be good and must meet two requirements, namely valid and reliable. If a research instrument has been tested for its validity and reliability, it can be seen which items are validly used in the study. Instruments that are invalid and unreliable are considered invalid and discarded.

\subsubsection{Validity test}

The validity test in this study was carried out on each item based on the value of the farmer's answer. The results were compared with the $r$ table to determine whether the research instrument was valid or not. For the trust variable, the research instrument consisted of 12 items questions with 63 farmers. The results of the trust validity test can be seen in table 1 follows.

Table 1. Trust validity test.

\begin{tabular}{|c|c|c|c|}
\hline No. & r count & r table & Information \\
\hline 1 & 0.790 & 0.2480 & Valid \\
\hline 2 & 0.719 & 0.2480 & Valid \\
\hline 3 & 0.801 & 0.2480 & Valid \\
\hline 4 & 0.771 & 0.2480 & Valid \\
\hline 5 & 0.762 & 0.2480 & Valid \\
\hline 6 & 0.791 & 0.2480 & Valid \\
\hline 7 & 0.810 & 0.2480 & Valid \\
\hline 8 & 0.872 & 0.2480 & Valid \\
\hline 9 & 0.799 & 0.2480 & Valid \\
\hline 10 & 0.638 & 0.2480 & Valid \\
\hline 11 & 0.600 & 0.2480 & Valid \\
\hline 12 & 0.808 & 0.2480 & Valid \\
\hline
\end{tabular}


Table 1 shows that, all question items on the confidence variable are valid, conclusions are drawn by comparing $r_{\text {arithmetic }}$ and $r_{\text {table. }}$. From the results of the calculation, it is found

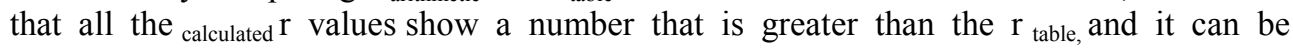
concluded that the research instrument used is valid for this study.

For the network variable the research instrument consisted of 12 questions with 63 farmers. The results of the network validity test can be seen in the following table.

Table 2. Objective wellbeing validity test.

\begin{tabular}{|l|c|c|c|}
\hline No. & r count & r table & Information \\
\hline 1 & 0.812 & 0.2480 & Valid \\
\hline 2 & 0.726 & 0.2480 & Valid \\
\hline 3 & 0.431 & 0.2480 & Valid \\
\hline 4 & 0.781 & 0.2480 & Valid \\
\hline 5 & 0.349 & 0.2480 & Valid \\
\hline 6 & 0.701 & 0.2480 & Valid \\
\hline 7 & 0.505 & 0.2480 & Valid \\
\hline 8 & 0.553 & 0.2480 & Valid \\
\hline 9 & 0.566 & 0.2480 & Valid \\
\hline 10 & 0.391 & 0.2480 & Valid \\
\hline 11 & 0.731 & 0.2480 & Valid \\
\hline 12 & 0.469 & 0.2480 & Valid \\
\hline
\end{tabular}

Table 2 shows that, all question items on the confidence variable are valid, conclusions are drawn by comparing $r_{\text {arithmetic }}$ and $r_{\text {table }}$. From the results of the calculation, it is found that all the calculated $r$ values show a number that is greater than the $r_{\text {table, }}$ and it can be concluded that the research instrument used is valid for this study.

\subsubsection{Reliability test}

Reliability test in this study was conducted in order to show the extent to which the results of measurements with the questionnaire can be trusted with the results obtained relatively consistent. $\mathrm{P}$ is for each item based on the value of the farmer's answer. The results are compared with table els to determine whether the research instrument is valid or not. The results of the research questionnaire reliability test can be seen in table 4 below.

Table 3. Trust reliability test.

\begin{tabular}{|l|l|c|c|c|}
\hline No. & Variable & r count & r table & Information \\
\hline 1 & Trust & 0.934 & 0.60 & Reliable \\
\hline 2 & Network & 0.937 & 0.60 & Reliable \\
\hline 3 & Objective Wellbeing & 0.820 & 0.60 & Reliable \\
\hline
\end{tabular}

Table 3 shows the sump wa entire item questions on va ribel trust, networking and welfare objective is Andal, a conclusion reached by comparing $r_{\text {arithmetic }}$ and $r_{\text {table }}$. From the results of the calculation, it is found that all the calculated $r$ values show a number that is greater than the $r_{\text {table, }}$ and it can be concluded that the research instrument used is valid for this study. 


\subsection{Farmers' household social capital}

\subsubsection{Confidence Level}

The level of trust is a variable that can describe the condition of the farmer's social capital. The belief that exists in the cocoa farming community in Tolada village can be in the form of a feeling of confidence that is created between farmers or farmers and other people that other people will do something as expected and provide support to each other both in daily activities, in community life and activities cocoa farming. The level of household trust of cocoa farmers in To Pepper Village can be seen in the following table.

Table 4. Farmers' confidence level.

\begin{tabular}{|l|c|c|}
\hline Category & Number of people & Percentage (\%) \\
\hline High & 13 & 21 \\
\hline Moderate & 41 & 65 \\
\hline Low & 9 & 14 \\
\hline Total & $\mathbf{6 3}$ & $\mathbf{1 0 0}$ \\
\hline
\end{tabular}

Table 4 shows that, in general, cocoa farmers in Tolada Village have a level of confidence in the medium category with 41 people with a percentage of $65 \%$, farmers with a high level of trust with 13 people with a percentage of $21 \%$, and farmers with a low level of trust with 9 people and a percentage of $14 \%$.

The level of confidence of farmers in the high, medium and low categories is influenced by the percentage of each indicator for measuring farmer confidence. The trust of farmers in the high category is influenced by honesty and responsibility of each farmer, both given and giving trust, this attitude is still well preserved in the daily life of farmers, indicated by the number of farmers who are willing to lend to one another agricultural equipment.

The level of trust of farmers in the high category is due to the fact that farmers have lived side by side for a long time, forming emotional bonds and fostering mutual trust aimed at farmers who are willing to entrust valuables with their neighbors or are willing to be entrusted with valuables by neighbors, either in the form of important document or in the form of cash owned by farmers.

The level of confidence of farmers who are in the medium category is influenced by the willingness of farmers to help each other in dealing with problems and get out of the difficulties they are experiencing, because not all farmers are able to provide assistance and solutions experienced by other farmers so that the assistance that can be given is highly dependent on the problems experienced and the capacity of other farmers who will contribute to solving problems together.

On the other hand, some farmers still have a low category of trust because some farmers do not trust other farmers to manage their cocoa gardens because they admit that they are not satisfied with their crops which tend to be less than optimal if their gardens are entrusted to others. The low category of trust is also influenced by the level of trust between farmers and cocoa traders, although farmers and traders / middlemen can decide the selling price of cocoa only by telephone, but some farmers are less willing to give their cocoa to middlemen for transport and the proceeds from the sale will be given a few days later, this is This is because farmers need capital for the cost of producing cocoa and the cost of daily living quickly, the lack of trust in the middlemen is also due to the middlemen's habit of stalling for payment of their cocoa sales so it is not exactly the day promised to farmers. 


\subsubsection{Network}

The network is formed because of mutual knowledge, mutual information and mutual assistance in implementing or overcoming a problem [25]. For the development of a community, various potentials and resources are needed, both internally and externally. The size of the cocoa farmer network in Tolada Village, Malangke District, North Luwu Regency can be seen by the indicator of the level of information disclosure, the level of cooperation, the benefit of farmer groups, the farmer network for access to production capital. The percentage and network owned by farmers measured on each network indicator can provide an overview of the condition of the social capital elements of the cocoa farmer network in Tolada Village, Malangke District, North Luwu Regency. The network owned by farmers can make it easier for farmers to solve cocoa plantation problems. The network of cocoa farmers in Tolada Village can be seen in the following table.

Table 5. Farmers network.

\begin{tabular}{|c|c|r|}
\hline Category & Number of people & Percentage (\%) \\
\hline High & 14 & 22 \\
\hline Moderate & 42 & 67 \\
\hline Low & 7 & 11 \\
\hline Total & $\mathbf{6 3}$ & $\mathbf{1 0 0}$ \\
\hline
\end{tabular}

Table 5 shows that, in general, cocoa farmers in Tolada Village have networks in the medium category with a total of 42 peoples with a percentage of $67 \%$, farmers with networks in the high category with a total of 14 people and a percentage of $22 \%$ and farmers with networks that are in the low category with a total number of 7 people with a percentage of $11 \%$.

The elements of social capital for the farmer network with the high, medium and low categories are influenced by the percentage of each indicator of the farmer network measurement. Farmers' networks with a high category can be seen from farmers who take advantage of their networks to form farmer groups that can make it easier for farmers to sustain their cocoa farming, farmers feel the need to join farmer groups because they can get many benefits, such as collaborating in post-harvest cocoa processing which results will result. Sold to farmer groups and the profits distributed to each member. In addition, joining a farmer group will make it easier for farmers to obtain agricultural production facilities because joining a farmer group is one of the requirements so that farmers can obtain fertilizer for their cocoa plants.

Networking with fellow farmers will make it easier for farmers to collaborate such as mutual cooperation to repair farm roads which will usually be damaged when the rainy season arrives, damaged road access will prevent farmers from coming to the cocoa plantation areas, networks of fellow farmers can also be used to do this. Mutual cooperation by working together to improve farm roads. Farmers' networks in the medium category are influenced by the ease of obtaining information, for example related to the latest types of fertilizers produced specifically for cocoa plants, some farmers are slow to find information like this, besides that there are still a small proportion of farmers who admit that they do not always get information or invitations for outreach or training activities.

The low category of farmer networks is influenced by farmer networks in accessing production capital, lack of capital for production for maintenance costs or for rejuvenating cocoa will hinder farmers' cocoa farming so that alternative production capital lending must be taken for the sustainability of cocoa plantation activities. Farmers' capital loans can be obtained from other farmers, financial institutions and traders who provide cocoa production facilities. Most farmers find it difficult to obtain capital loans from fellow farmers because farmers have the same need for production capital, while for bank financial 
institutions, farmers are usually constrained by conditions that must be met, both collateral and other requirements that must be met, interest that must be paid or when payment must be agreed upon, production capital loans tend to be easier for farmers to obtain from input production traders who can directly obtain loans in the form of pesticides and fertilizers which can usually be paid when the cocoa season arrives, but farmers also have to pay relatively higher prices than other farmers who directly pay to merchants. This affects the farmer network in the low category.

\subsection{Objective welfare levels}

The objective welfare of the household is measured by land area, housing conditions and the amount of family needs per month. The amount of family expenditure is seen from the percentage of expenditure for food needs and non-food needs. Food expenditure is the amount of household expenditure aimed at meeting food consumption to fulfill the nutrition needed by the body in order to obtain energy. Non-food expenditure is expenditure intended for clothing, food, communication and social energy. The objective level of farmer welfare can be seen in the following table.

Table 6. Objective farmer welfare levels.

\begin{tabular}{|c|c|r|}
\hline Category & Number of people & Percentage (\%) \\
\hline High & 10 & 19 \\
\hline Moderate & 41 & 65 \\
\hline Low & 12 & 16 \\
\hline Total & $\mathbf{6 3}$ & $\mathbf{1 0 0}$ \\
\hline
\end{tabular}

Table 6 shows that, in general, cocoa farmers in Tolada Village have a level of welfare in the medium category with 41 people with a percentage of $65 \%, 10$ people with a high level of trust, $19 \%$ for cocoa farmers, and 12 people with a low level of trust and a percentage of $16 \%$. Factors that influence the objective welfare of the farmer family are family expenses, families that have high expenditures will increase the objective welfare because high expenditures tend to have high incomes so that family expenses can reflect family income as well.

\subsection{The relationship between social capital and the objective welfare of farmer households}

The social capital component can improve efficiency in a society by facilitating coordinated actions [26]. The objective welfare category that is owned by cocoa farmers in Tolada Village cannot be separated from the existence of social capital they have. With the social capital they have, the life of farmers takes place in a close, trusting manner and can take advantage of their existing networks to collaborate in social life. The level of objective welfare can be determined by the condition of social capital in farmer households as seen from the element of social capital. The percentage of elements of social capital, trust and objective welfare of farmer households can be seen in the following table.

Table 7 shows that, most of the cocoa farmer households that have a moderate level of trust are also at an objective level of welfare with a moderate category, namely 32 people and a percentage of $50 \%$. Respondents with a low level of social capital and low objective welfare were 6 people with a percentage of $10 \%$. Respondents with a high level of social capital and high objective welfare were 6 people with a percentage of $10 \%$. Farmers' trust can affect the objective conditions of farmer household welfare, with the trust that farmers 
have can build relationships that can reduce transaction costs, namely costs arising from the exchange process, costs of making contacts, contracts and control [27].

Table 7. Percentage percentage of social capital elements of trust and objective welfare of farmer households.

\begin{tabular}{|l|c|c|c|c|c|c|c|c|}
\hline \multirow{3}{*}{ Trust } & \multicolumn{9}{|c|}{ Objective Wellbeing } & \multicolumn{2}{c|}{ Total } \\
\cline { 2 - 8 } & \multicolumn{2}{|c|}{ Low } & \multicolumn{2}{|c|}{ Moderate } & \multicolumn{2}{c|}{ High } & \multicolumn{2}{c|}{} \\
\cline { 2 - 8 } & $\mathbf{N}$ & $\mathbf{\%}$ & $\mathbf{N}$ & $\mathbf{\%}$ & $\mathbf{N}$ & $\mathbf{\%}$ & $\mathbf{N}$ & $\%$ \\
\hline Low & 6 & 10 & 3 & 5 & 0 & 0 & 9 & 15 \\
\hline Moderate & 5 & 8 & 32 & 50 & 4 & 6 & 41 & 64 \\
\hline High & 1 & 1 & 6 & 10 & 6 & 10 & 13 & 21 \\
\hline Total & $\mathbf{1 2}$ & $\mathbf{1 9}$ & $\mathbf{4 1}$ & $\mathbf{6 5}$ & $\mathbf{1 0}$ & $\mathbf{1 6}$ & $\mathbf{6 3}$ & $\mathbf{1 0 0}$ \\
\hline
\end{tabular}

The condition of farmer social capital farmer social capital is also seen from the percentage of elements of social network capital and the objective welfare of farmer households can be seen in the following table.

Table 8. Percentage of social network and objective welfare elements of farmer households.

\begin{tabular}{|l|c|c|c|c|c|c|c|c|}
\hline \multirow{2}{*}{ Network } & \multicolumn{9}{|c|}{ Objective Wellbeing } & \multicolumn{2}{c|}{ Total } \\
\cline { 2 - 9 } & \multicolumn{2}{|c|}{ Low } & \multicolumn{2}{|c|}{ Moderate } & \multicolumn{2}{c|}{ High } & \multicolumn{2}{c|}{} \\
\cline { 2 - 9 } & $\mathrm{N}$ & $\%$ & $\mathrm{~N}$ & $\%$ & $\mathrm{~N}$ & $\%$ & $\mathrm{~N}$ & $\%$ \\
\hline Low & 7 & 12 & 0 & 0 & 0 & 0 & 7 & 12 \\
\hline Moderate & 5 & 8 & 35 & 56 & 2 & 3 & 43 & 67 \\
\hline High & 0 & 0 & 6 & 8 & 8 & 13 & 14 & 21 \\
\hline \multirow{2}{*}{ Total } & $\mathbf{2}$ & $\mathbf{0}$ & $\mathbf{1}$ & $\mathbf{4}$ & $\mathbf{0}$ & $\mathbf{6}$ & $\mathbf{3}$ & $\mathbf{0 0}$ \\
\hline
\end{tabular}

Table 8 shows that, most of the cocoa farmer households that have networks with the medium category are also at the objective level of welfare with the medium category, namely 35 people and a percentage of $56 \%$. Respondents with a low level of social capital and low objective welfare were 7 people with a percentage of $12 \%$. Respondents with a high level of social capital and high objective welfare were 10 people with a percentage of $16 \%$.

Table 9. The relationship between social capital elements, trust and welfare objectives of farmers' households.

\begin{tabular}{|c|c|c|c|c|}
\hline \multicolumn{5}{|c|}{ Correlations } \\
\hline & & & trust & Objective \\
\hline \multirow[t]{6}{*}{$\begin{array}{l}\text { Spearm } \\
\text { an's rho }\end{array}$} & \multirow[t]{3}{*}{ Trust } & $\begin{array}{l}\text { Correlation } \\
\text { Coefficient }\end{array}$ & 1,000 & $.668^{* *}$ \\
\hline & & $\begin{array}{l}\text { Sig. (2- } \\
\text { tailed) }\end{array}$ & . & .000 \\
\hline & & $\mathrm{N}$ & 63 & 63 \\
\hline & \multirow{3}{*}{$\begin{array}{l}\text { Objectiv } \\
\text { e } \\
\text { Wellbei } \\
\text { ng }\end{array}$} & $\begin{array}{l}\text { Correlation } \\
\text { Coefficient }\end{array}$ & .668 & 1,000 \\
\hline & & $\begin{array}{l}\text { Sig. (2- } \\
\text { tailed) }\end{array}$ & .000 & . \\
\hline & & $\mathrm{N}$ & 63 & 63 \\
\hline
\end{tabular}


The relationship between social capital and the objective welfare of the farmer household can be largely determined by the elements of social capital. The relationship between elements of social capital, trust and objective welfare can be seen in the following table.

Table 9 shows that the correlation between the elements of the social capital of trust and well-being objectively at 0.668 that is between the value of a correlation of $0.60-$ of 0,79 yan $g$ means a strong relationship. Signs Star $(* *)$ showed a significant correlation at a significance level of 0.01 , meaning that the level of accuracy of the analysis results of $99 \%$ and $1 \%$ error. The correlation coefficient of 0.668 , which has a positive value, shows that the elements of social capital, trust and objective welfare, have a unidirectional relationship, meaning that if the elements of trust social capital increase, the objective welfare will also increase.

Other elements of social capital measured in the study are the elements of network social capital. The relationship between the elements of network social capital and objective welfare can be seen in table 36 below.

Table 10. The relationship between social capital elements, network and objective welfare of farmers household.

\begin{tabular}{|c|c|c|c|c|}
\hline \multicolumn{5}{|c|}{ Correlations } \\
\hline & & & Network & $\begin{array}{l}\text { Objective } \\
\text { Wellbeing }\end{array}$ \\
\hline \multirow[t]{6}{*}{$\begin{array}{l}\text { Spearman's } \\
\text { rho }\end{array}$} & \multirow[t]{3}{*}{ Network } & $\begin{array}{l}\text { Correlation } \\
\text { Coefficient }\end{array}$ & 1,000 & $.728^{* *}$ \\
\hline & & $\begin{array}{l}\text { Sig. (2- } \\
\text { tailed) }\end{array}$ & & .000 \\
\hline & & $\mathrm{N}$ & 63 & 63 \\
\hline & \multirow[t]{3}{*}{$\begin{array}{l}\text { Objective } \\
\text { Wellbeing }\end{array}$} & $\begin{array}{l}\text { Correlation } \\
\text { Coefficient }\end{array}$ & $.728^{* *}$ & 1,000 \\
\hline & & $\begin{array}{l}\text { Sig. (2- } \\
\text { tailed) }\end{array}$ & .000 & \\
\hline & & $\mathrm{N}$ & 63 & 63 \\
\hline
\end{tabular}

Table 10 shows that the correlation between the elements of social capital and welfare networks objective of 0.728 which is located between the value of a correlation of 0.60 - of 0.79 which means a strong relationship. Signs Star $(* *)$ showed a significant correlation at a significance level of 0.01 , meaning that the level of accuracy of the analysis results of $99 \%$ and $1 \%$ error. The correlation coefficient of 0.728 which has a positive value indicates that the elements of network social capital and objective welfare have a unidirectional relationship, meaning that if the elements of network social capital increase, the objective welfare will also increase.

The strength and weakness of the relationship between social capital and the objective welfare of farmer households is largely determined by the condition of the elements of social capital that develop in community life and their relationship with objective welfare. The relationship between social capital and the objective welfare of farmer households can be seen in the following table.

Table 11 shows that the correlation value of social capital and well-being objectively at 0.718 that is between the value of a correlation of 0.60 - of 0,79 which means a strong relationship. Signs Star (**) showed a significant correlation at a significance level of 0.01 , meaning that the level of accuracy of the analysis results of $99 \%$ and $1 \%$ error. The correlation coefficient value of 0.718 which is positive indicates that the two variables are 
unidirectional. This means that if the social capital variable $(\mathrm{X})$ increases, the objective welfare variable (Y) also increases, this also applies to the opposite, namely if the social capital variable $(\mathrm{X})$ decreases, the objective welfare variable $(\mathrm{Y})$ also decreases.

Table 11. The Relationship between social capital and welfare objectives of farmer households.

\begin{tabular}{|l|l|l|c|c|}
\hline \multicolumn{3}{|c|}{ Correlations } \\
\hline \multirow{2}{|c|}{$\begin{array}{l}\text { Spearman's } \\
\text { rho }\end{array}$} & $\begin{array}{c}\text { Social } \\
\text { Capital }\end{array}$ & $\begin{array}{c}\text { Objective } \\
\text { Wellbeing }\end{array}$ \\
\cline { 3 - 5 } & & $\begin{array}{l}\text { Correlation } \\
\text { Coefficient }\end{array}$ & 1,000 & $.718^{* *}$ \\
\cline { 3 - 5 } & Sig. (2-tailed) &. & .000 \\
\cline { 3 - 5 } & $\mathrm{N}$ & 63 & 63 \\
\cline { 2 - 5 } & $\begin{array}{l}\text { Objective_ } \\
\text { Wellbeing }\end{array}$ & $\begin{array}{l}\text { Correlation } \\
\text { Coefficient }\end{array}$ & $.718^{* *}$ & 1,000 \\
\cline { 3 - 5 } & Sig. (2-tailed) & .000 &. \\
\cline { 3 - 5 } & $\mathrm{N}$ & 63 & 63 \\
\hline
\end{tabular}

\section{Conclusion}

Based on the results of research and discussion that has been described, it can be concluded that the network element of social capital and trust Tolada Village farmers, slams a tan Malangke North Luwu at the level of social capital in the medium category. With the social capital they have, the life of farmers takes place in an intimate, mutual trust and can take advantage of their existing networks to collaborate in solving agricultural problems. The strength and weakness of the relationship between social capital and the objective welfare of farmer households is largely determined by the condition of the social capital they have. Social capital and objective welfare have a strong and unidirectional relationship, which means that if social capital increases, objective welfare also increases.

\section{References}

1. J. Rumagit, J. F. J. Timban, and C. R. Ngangi, Agri-Sosioekonomi 15, 453 (2019).

2. P. E. Prasetyo, A. Setyadharma, and N. R. Kistanti, Int. J. Sci. Technol. Res. 9, 6627 (2020).

3. N. Busthanul, M. S. S. Ali, A. Kamaluddin, Heliawaty, and M. T. Saputra, Pengabdi. Kpd. Masy. 789 (2016).

4. P. E. Prasetyo, A. Setyadahrma, and N. R. Kistanti, Int. J. Sci. Technol. Res. 9, 1838 (2020).

5. Kushandajani, Otonomi Desa Berbasis Modal Sosial Dalam Perspektif Socio-Legal (Jurusan Ilmu Pemerintahan Fisip Undip, Semarang, 2008).

6. M. Harahap and S. Herman, J. Agribus. Sci. 1, 49 (2017).

7. E. Thobias, A. K. Tungka, and J. J. Rogahang, Acta Diurna 1 (2013).

8. E. Juita K. Nababan, R. Qurniati, and A. Kustanti, J. Sylva Lestari 4, 89 (2016).

9. B. Cahyono and A. Adhiatma, Conf. Business, Accounting, Manag. 1, 131 (2012).

10. Luginaah, R. B. Kerr, E. Lupafya, and L. Dakishoni, Int. J. Sustain. Dev. World Ecol. 7, 1 (2020).

11. O. Kolade, O. Mafimisebi, and O. Aluko, Int. J. Palgrave Handb. Agric. Rural Dev. Africa 109 (2020).

12. N. T. Puspita, R. Qurniati, and I. G. Febryano, J. Sylva Lestari 20, 54 (2020).

13. R. Qurniati, I. G. Febryano, and D. Zulfiani, Biodiversitas 18, 1201 (2017). 
14. S. Ekawati and D. Ridho Nurrochmat, J. Anal. Kebijak. Kehutan. 11, 40 (2014).

15. Nurrochmat, D. Ridho, D. Darusman, and M. Ekayani., Kebijakan Pembangunan Kehutanan Dan Lingkungan Teori Dan Implementasi (PT Penerbit IPB Press, Bogor, 2016).

16. T. Pranadji, J. Agro Ekon. Indones. Agency Agric. Res. Dev. 24, 178 (2016).

17. Badan Pusat Statistik Sulawesi Selatan, Provinsi Sulawesi Selatan Dalam Angka 2018 76 (2018).

18. Badan Pusat Statistik Sulawesi Selatan, Provinsi Sulawesi Selatan Dalam Angka 2018 68 (2019).

19. N. Fauziah, Hubungan Modal Sosial Dengan Kesejahteraan Ekonomi Rumah Tangga Petani, Institut Pertanian Bogor, 2015.

A. Mulyana, Inst. Pertan. Bogor (2018).

20. R. Rijanta, R. Hizbaron, and M. Baiquni, Modal Sosial Dalam Manajemen Bencana (Gadjah Mada University Press, Yogyakarta, 2018).

21. N. A. Herbawanti, Inst. Pertan. Bogor (2019).

22. Kusumaningrum, Inst. Pertan. Bogor (2017).

23. F. Ali and A. G. Kadir, Manajemen Penelitian Berbasis Sasaran (Gava Media, Bandung, 2014).

24. R. M. Z. Lawang, Capital Social: Dalam Perspektif Sosiologis Suatu Pengantar (Universitas Indonesia (FISIP UI) Press, Depok, 2004).

25. R. D. Putnam, Am. Prospect 4, 35 (1993).

26. Heliawaty, Modal Sosial, Perilaku Inovatif Dan Ekonomi Petani Dataran Tinggi Dan Dataran Rendah Di Kabupaten Bantaeng Sulawesi Selatan, Universitas Hasanuddin, 2015. 